\title{
Multiplicative synergistic risk of hepatocellular carcinoma development among hepatitis $B$ and $C$ co-infected subjects in HBV endemic area: a community-based cohort study
}

\author{
Jin-Kyoung Oh ${ }^{1}$, Hai-Rim Shin ${ }^{1,2^{*}}$, Min Kyung Lim ${ }^{1}$, Heeyoun Cho ${ }^{1}$, Dong- $\|$ Kim $^{3}$, Youngmee Jee ${ }^{4,5}$,
} Haesun Yun ${ }^{5}$ and Keun-Young Yoo ${ }^{6}$

\begin{abstract}
Background: There has been limited study on the effect of infection with different hepatitis $\mathrm{C}$ virus (HCV) genotypes on the risk of hepatocellular carcinoma (HCC) in hepatitis B virus (HBV) endemic regions of Asia.

Methods: Hazard ratios of HCC development were estimated for HBV and HCV co-infected subjects among a community-based prospective cohort. HCV genotype was determined in HCV RNA-positive samples. Incident HCC cases were identified through linkage to the cancer registry.

Results: HCC incidence was 79 per 100,000 person-years in the study population (50 incident cases among 6,694 individuals within 63,170 person-years with an average of 9.4 years of follow-up); seroprevalence of HBsAg and anti-HCV was 5.2\% and 5.6\%. Adjusted hazard ratios of HCC by HBsAg positivity and anti-HCV positivity were 13.3 (Cl: 7.3-24.4) and 6.7 (Cl: 3.6-12.6). HRs of HBV and HCV monoinfection, and HBV/HCV coinfection were 17.1 (Cl: 8.4-34.8), 10.4 (Cl: 4.9-22.1) and 115.0 (Cl: 32.5-407.3). Multiplicative synergistic effect of HBV/HCV coinfection on HCC risk was also observed (synergy index: 4.5, Cl: 1.3-15.5). Infection with HCV genotype 1 (HR: 29.7, Cl: 13.6-46.8) and mixed infection with genotype 1 and 2 (HR: 68.7, Cl: 16.4-288.4) significantly elevated HCC risk, much higher than HBV infection.
\end{abstract}

Conclusions: The effect of differences in HCV genotype and the multiplicative synergistic effect of HBV/HCV coinfection on HCC risk shown in the present study underline the need for comprehensive identification of hepatitis infection status in order to prevent and control HCC in this HBV endemic area.

Keywords: Hepatitis B virus, Hepatitis C virus, Hepatocellular carcinoma, Cohort study

\section{Background}

Epidemiologic and experimental evidence has shown that chronic infection with hepatitis $B$ and $C$ virus (HBV, $\mathrm{HCV}$ ) is a major risk factor for hepatocellular carcinoma (HCC) [1,2]. The highest incidence rates of HCC come from Southeast Asia including China and the Republic of

\footnotetext{
* Correspondence: Shinh@wpro.who.int

${ }^{1}$ National Cancer Control Institute, National Cancer Center, Goyang, Republic of Korea

${ }^{2}$ Non Communicable Diseases and Health Promotion, World Health Organization Western Pacific Regional Office, 1000 UN Avenue, Manila, Philippines

Full list of author information is available at the end of the article
}

Korea, and sub-Saharan Africa, where HCC is frequently caused by HBV infection, and from Japan, where HCC is predominantly caused by $\mathrm{HCV}$ [3]. $\mathrm{HBV}$ and $\mathrm{HCV}$ infection increase HCC risk some 12- to 14-fold and this risk differs according to whether the infection is an HBV or $\mathrm{HCV}$ monoinfection, or an $\mathrm{HBV} / \mathrm{HCV}$ coinfection, and depends on which genotypes of the viruses are involved, and their viral load [4-9].

In particular, distribution of $\mathrm{HCV}$ genotypes varies according to geographic regions, which raises several issues related to their transmission and treatment. There were not so many studies on risk difference in $\mathrm{HCV}$ genotypes in general population. Some studies, including

\section{Biomed Central}


prospective cohort and meta-analysis, have suggested that $\mathrm{HCV}$ genotype $1 \mathrm{~b}$ plays the most important role in HCC development $[8,10,11]$ but most studies included in the meta-analysis were based on patients with chronic hepatitis or liver cirrhosis [8].

In Korea, where the incidence rate of $\mathrm{HCC}$ is high (24.5 per 100,000 [12]), the prevalence of HCV (1.3\% [13]) infection is lower than that of HBV (3.2\% [14]). A recent meta-analysis of Korean data showed that the pooled relative risk (RR) (11.5 for both sexes) of HCC among individuals positive for antibodies against HCV (anti$\mathrm{HCV}$ ) was also lower than that among individuals positive for hepatitis B surface antigen (HBsAg) (24.4 in men and 33.7 in women) [15]. HCV genotypes $1 \mathrm{~b}$ and $2 \mathrm{a}$ were reported to be the most prevalent among six known $\mathrm{HCV}$ genotypes and at least 30 subtypes [13], whereas genotype $\mathrm{C}$ was predominant (99\%) among the HBV genotypes [16-18]. An additive effect of HBV/HCV coinfection, as well as a differing risk conferred by different $\mathrm{HCV}$ genotypes on HCC development, were suggested by a few epidemiologic studies, including a recent metaanalysis [5]. However, there are a very limited number of studies on the impact of HCV infection on HCC development in Korea. Indeed, all of the studies included in the aforementioned meta-analysis were case-control studies, the sample sizes of which were relatively small.

In this context, using a community-based prospective cohort design, the present study investigated HCC risk in relation to $\mathrm{HBV}$ infection, $\mathrm{HCV}$ infection and other risk factors, and evaluated the difference in risk between $\mathrm{HBV}$ or $\mathrm{HCV}$ monoinfection and $\mathrm{HBV} / \mathrm{HCV}$ coinfection in the Republic of Korea. HCC risk according to $\mathrm{HCV}$ genotype was also investigated.

\section{Methods}

\section{Ethics statement}

The study protocol was approved by the Institutional Review Boards of the Seoul National University Hospital and the National Cancer Center of Korea. All study participants signed an informed consent form before inclusion into their respective cohort.

\section{Study participants}

A community-based prospective cohort study was conducted in a rural area of Korea between 1993 and 2003. Briefly, the cohort was designed to investigate the relationship between environmental exposures, lifestyle factors, host factors and the risk of cancer in Korea. Members of the cohort aged 30 years or older who were residents of Haman (county) in Kyeongsangnam-do (province), a rural area in the Southeastern part of the country, with the highest reported HCC incidence, were included in the present study. After excluding 105 cohort members with existing cancer at enrollment, 28 cohort members who developed incident cancer within 6 months of enrollment (considering asymptomatic period and late detection of cancer), and 51 with incident non-Hodgkin lymphoma and cholangiocarcinoma (as these cancers are also caused by HCV infection) [19], 6694 cancer-free members from the cohort were included in the final analysis.

\section{Data collection}

Cohort members completed a questionnaire and provided a blood/urine sample during a health examination at the time of enrollment into the study. Detailed data collection was described previously [20,21].

Socio-demographics, tobacco smoking and alcohol drinking, $\mathrm{HBV}$ and $\mathrm{HCV}$ infection status, results of liver function test (alanine aminotransferase [ALT] and aspartate aminotransferase [AST]), fasting blood sugar (FBS), and history of acupuncture/transfusion were included in this analysis. Alcohol consumption was categorized as follows: no drinking (0 g/day), moderate drinking (0.1$23.9 \mathrm{~g} /$ day) and heavy drinking ( $\geq 24.0 \mathrm{~g} /$ day) [22]. Body mass index (BMI) was calculated from direct measures of height and weight and categorized according to the World Health Organization standard for Asians as follows: underweight $\left(<18.5 \mathrm{~kg} / \mathrm{m}^{2}\right)$, normal (18.5$\left.22.9 \mathrm{~kg} / \mathrm{m}^{2}\right)$, overweight $\left(23.0-24.9 \mathrm{~kg} / \mathrm{m}^{2}\right)$, and obese $\left(\geq 25.0 \mathrm{~kg} / \mathrm{m}^{2}\right)[23]$.

\section{HBV and HCV testing}

Enzyme immunoassay (AxSYM, Abbott Laboratories, Abbott Park, Illinois, USA) was used to determine HBV and HCV infection. Samples were tested for seropositivity to HBsAg, antibodies against hepatitis B surface antigen (anti-HBs) and anti-HCV for all study participants. HCV RNA viremia was confirmed by nested reverse transcript-polymerase chain reaction or by nucleic acid testing (NAT) (COBAS AMPLICOR HCV MONITOR test, version 2.0, Roche Molecular Systems, Branchburg, New Jersey, USA) in anti-HCV-positive samples. HCV genotypes were determined by the Okamoto's method [24] or by line-probe assay (VERSANT HCV genotype assay (LiPA), Innogenetics, Ghent, Belgium) in $\mathrm{HCV}$ RNA-positive samples.

\section{Cancer ascertainment}

On December 31, 2008, 50 HCC cases were identified in the study population through computerized record linkage to the Korea National Cancer Incidence Database of the Korean Central Cancer Registry, a very reliable registry showing $95 \%$ completeness [12].

\section{Statistical analysis}

The Cox proportional hazards model was used to estimate the adjusted hazard ratios and corresponding 95\% 
Table 1 General characteristics of 6,694 study participants in Korea, 1993-2003

\begin{tabular}{|c|c|c|c|}
\hline Characteristic & & $\begin{array}{l}\text { Male } \\
\text { N (\%) }\end{array}$ & $\begin{array}{l}\text { Female } \\
\mathrm{N}(\%)\end{array}$ \\
\hline Gender & & 2682 & 4012 \\
\hline \multirow[t]{4}{*}{ Age (years) } & $<50$ & $698(26.0)$ & 1090(40.6) \\
\hline & $50-59$ & $829(30.9)$ & $1238(46.2)$ \\
\hline & $60-69$ & $845(31.5)$ & $1240(46.2)$ \\
\hline & $\geq 70$ & $310(11.6)$ & $444(16.6)$ \\
\hline \multirow[t]{4}{*}{ Marital status } & Single/Divorced & $51(1.9)$ & $39(1.5)$ \\
\hline & Married & $2138(79.7)$ & $2422(90.3)$ \\
\hline & Widowed & $105(3.9)$ & $922(34.4)$ \\
\hline & Unknown & $388(14.5)$ & $629(23.5)$ \\
\hline \multirow[t]{3}{*}{ Education } & Under middle school & $1029(38.4)$ & $2490(92.8)$ \\
\hline & Upper middle school & $1634(60.9)$ & $1493(55.7)$ \\
\hline & Unknown & $19(0.7)$ & $29(1.1)$ \\
\hline \multirow[t]{3}{*}{ Job } & Farmer & 1598(59.6) & $2136(79.6)$ \\
\hline & Other & $1084(40.4)$ & $1876(69.9)$ \\
\hline & Unknown & $455(17.0)$ & $717(26.7)$ \\
\hline \multirow[t]{4}{*}{ Smoking } & Non-smoker & $554(20.7)$ & $3587(133.7)$ \\
\hline & Ex-smoker & $521(19.4)$ & $66(2.5)$ \\
\hline & Current smoker & $1596(59.5)$ & $337(12.6)$ \\
\hline & Unknown & $11(0.4)$ & $22(0.8)$ \\
\hline \multirow[t]{4}{*}{ Alcohol drinking } & Non-drinker & $813(30.3)$ & $3437(128.2)$ \\
\hline & Ex-drinker & $246(9.2)$ & $66(2.5)$ \\
\hline & Current drinker & $1604(59.8)$ & $470(17.5)$ \\
\hline & Unknown & $19(0.7)$ & $39(1.5)$ \\
\hline \multirow[t]{4}{*}{$\mathrm{BMI}\left(\mathrm{Kg} / \mathrm{m}^{2}\right)$} & $<23$ & 1392(51.9) & $1648(61.4)$ \\
\hline & $23-25$ & $644(24)$ & $942(35.1)$ \\
\hline & $\geq 25$ & $591(22)$ & $1347(50.2)$ \\
\hline & Unknown & $55(2.1)$ & $75(2.8)$ \\
\hline \multirow[t]{3}{*}{$\begin{array}{l}\text { Acupuncture } \\
\text { history }\end{array}$} & No & $1192(44.4)$ & $1408(52.5)$ \\
\hline & Yes & $1183(44.1)$ & $2103(78.4)$ \\
\hline & Unknown & $307(11.4)$ & $501(18.7)$ \\
\hline \multirow[t]{3}{*}{$\begin{array}{l}\text { Blood transfusion } \\
\text { history }\end{array}$} & No & 1890(70.5) & $2744(102.3)$ \\
\hline & Yes & $85(3.2)$ & $191(7.1)$ \\
\hline & Unknown & $707(26.4)$ & $1077(40.2)$ \\
\hline \multirow[t]{3}{*}{$\mathrm{HBsAg}$} & Negative & 6113(227.9) & 2437(90.9) \\
\hline & Positive & $349(13)$ & $154(5.7)$ \\
\hline & Unknown & $232(8.7)$ & $91(3.4)$ \\
\hline \multirow[t]{3}{*}{ Anti-HBs } & Negative & $1151(42.9)$ & $1652(61.6)$ \\
\hline & Positive & 1422(53) & 2200(82) \\
\hline & Unknown & $109(4.1)$ & 160(6) \\
\hline \multirow[t]{3}{*}{ Anti-HCV } & Negative & 2456(91.6) & $3627(135.2)$ \\
\hline & Positive & 133(5) & 242(9) \\
\hline & Unknown & 93(3.5) & $143(5.3)$ \\
\hline
\end{tabular}

Table 1 General characteristics of 6,694 study participants in Korea, 1993-2003 (Continued)

\begin{tabular}{llll}
\hline FBS $(\mathrm{mg} . \mathrm{dL})$ & $<100 \mathrm{mg} / \mathrm{dL}$ & $1173(43.7)$ & $1865(69.5)$ \\
\hline & $100 \mathrm{mg} / \mathrm{dL}-126 \mathrm{mg} / \mathrm{dL}$ & $458(17.1)$ & $744(27.7)$ \\
\hline & $>=126 \mathrm{mg} / \mathrm{dL}$ & $256(9.5)$ & $330(12.3)$ \\
\hline ALT $(\mathrm{U} / \mathrm{L})$ & Unknown & $795(29.6)$ & $1073(40)$ \\
\hline & $\geq 30 U / \mathrm{L}$ & $1799(67.1)$ & $3284(122.4)$ \\
\hline AST $(\mathrm{U} / \mathrm{L})$ & Unknown & $756(28.2)$ & $594(22.1)$ \\
\hline & $<35 U / L$ & $127(4.7)$ & $134(5)$ \\
\hline & $\geq 35 U / L$ & $1794(66.9)$ & $3338(124.5)$ \\
\hline & Unknown & $759(28.3)$ & $535(19.9)$ \\
\hline
\end{tabular}

SD, standard deviation; BMI, body mass index; $\mathrm{HBsAg}$, hepatitis B surface antigen; anti-HBs, antibodies against hepatitis B surface antigen; anti-HCV, antibodies against hepatitis C virus; FBS, fasting blood sugar; ALT, alanine aminotransferase; AST, aspartate aminotransferase.

confidence intervals (CIs) in order to assess the independent contribution of each risk factor to the development of HCC, using SAS statistical software version 9.1 (SAS Institute, Inc., North Carolina, USA). The adjusted population-attributable fraction and the $95 \%$ CIs of HCC associated with $\mathrm{HBV}$ or $\mathrm{HCV}$ infection in the study population was estimated using STATA software version 10.0 (StataCorp, Texas, USA). The synergistic effect of $\mathrm{HBV} / \mathrm{HCV}$ coinfection was computed by applying the synergy index (SI) proposed by Rothman [25,26].

\section{Results}

The demographic characteristics of the cohort are shown in Table 1. Tobacco smoking, alcohol drinking, obesity and history of acupuncture were very common (28.9\%, $31.3 \%, 29.5 \%$ and $49.1 \%$, respectively) in the study population, whereas history of blood transfusion was relatively rare (4.1\%). The seroprevalence of $\mathrm{HBsAg}$, anti-HBs and anti-HCV was $5.2 \%, 56.4 \%$ and $5.6 \%$, respectively (Table 1).

The incidence of HCC in the study population was 79.2 per 100,000 person-years ([34 men and 16 women] 50 incident cases among 6,694 individuals within 63,170 person-years with an average of 9.4 years of follow-up).

Table 2 shows the HRs and corresponding 95\% CIs of HCC according to selected risk factors. Adjusted HRs of developing HCC by HBsAg positivity and by anti$\mathrm{HCV}$ positivity were 13.3 (95\% $\mathrm{CI}=7.3-24.4)$ and 6.7 (95\% CI=3.6-12.6), respectively. Higher AST $(\geq 30 \mathrm{u} / \mathrm{L})$ and ALT $(\geq 35 \mathrm{u} / \mathrm{L})$ levels were significantly related to increased HCC risk. However the other potential risk factors except heavy alcohol drinking ( $\mathrm{aHR}=2.2$, 95\% $\mathrm{CI}=1.1-4.4)$ were not significantly related to HCC risk in the multivariate model. 
Table 2 Relative risks (RRs) and 95\% confidence intervals (Cls) of hepatocellular carcinoma (HCC) according to selected characteristics

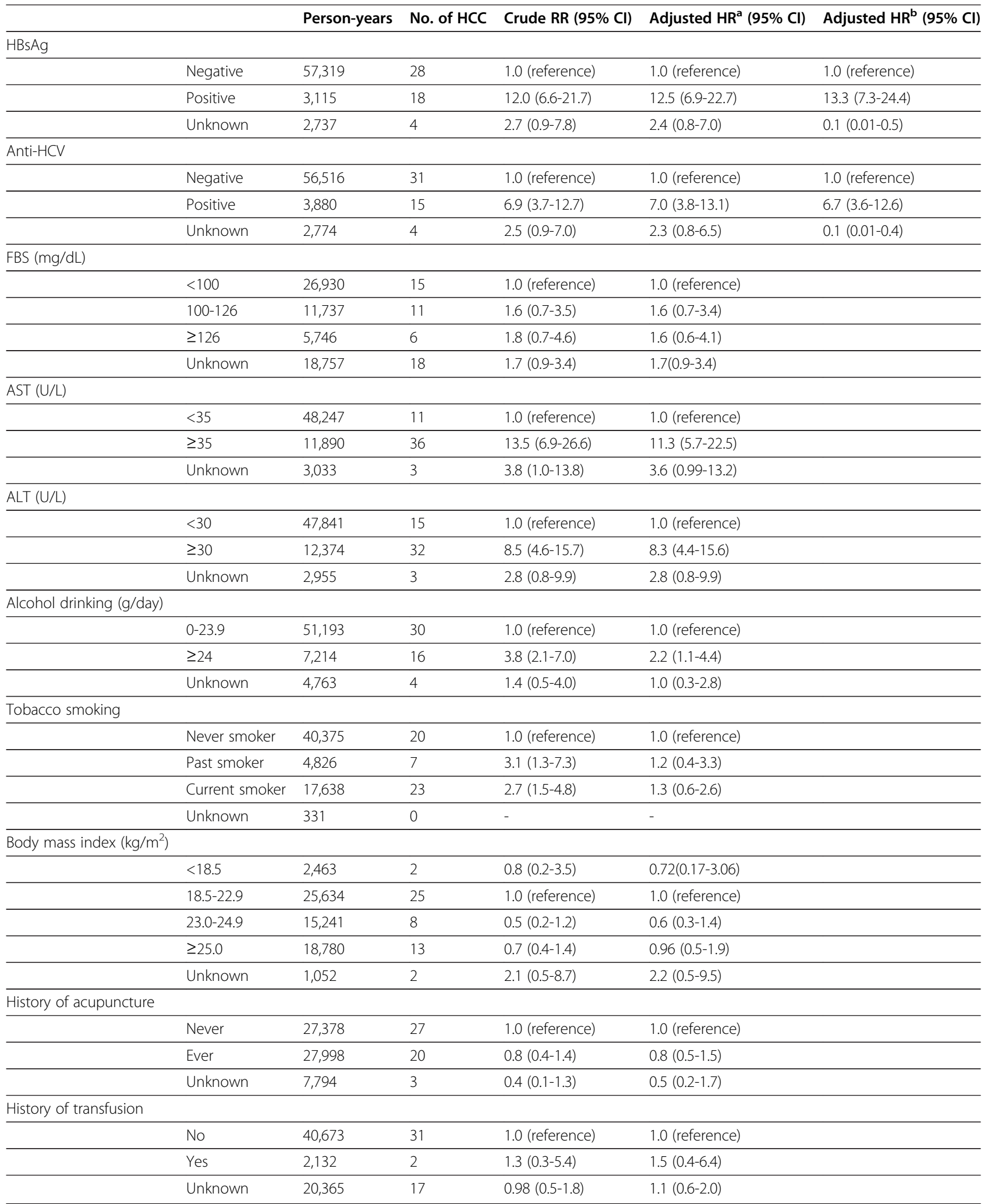

HBsAg, hepatitis B surface antigen; anti-HCV, antibodies against hepatitis C virus; FBS, fasting blood sugar; ALT, alanine aminotransferase; AST, aspartate aminotransferase. ${ }^{\text {aAge- }}$ and sex-adjusted. ${ }^{\mathrm{b}} \mathrm{Age}-$, sex- and HBsAg/anti-HCV positivity-adjusted. 
Table 3 Hazard Ratios (HRs) and 95\% confidence intervals (Cls) of hepatocellular carcinoma (HCC) according to hepatitis B and C virus infection status

\begin{tabular}{lllll}
\hline Infection status & No. of subjects & Person-years & No. of $\mathbf{H C C}$ & $\left.\mathbf{H R}^{\mathbf{a}} \mathbf{( 9 5 \%} \mathbf{C l}\right)$ \\
\hline $\mathrm{HBsAg}(-) /$ anti-HCV(-) & 5744 & 53,504 & 16 & 1.0 (reference) \\
\hline $\mathrm{HBsAg}(+) /$ anti-HCV(-) & 335 & 2,981 & 15 & $17.1(8.4-34.8)$ \\
\hline $\mathrm{HBsAg}(-) /$ anti-HCV(+) & 360 & 3,731 & 12 & $10.4(4.9-22.1)$ \\
\hline $\mathrm{HBsAg}(+) /$ anti-HCV(+) & 14 & 133 & 3 & $115.0(32.5-407.3)$ \\
\hline
\end{tabular}

HBsAg, hepatitis B surface antigen; anti-HCV, antibodies against hepatitis $\mathrm{C}$ virus. ${ }^{\mathrm{a} H R}$ : age- and sex-adjusted. ${ }^{\mathrm{b}} \mathrm{SI}$ : synergy index $=\left(\mathrm{RR}_{11}-1\right) /\left(\mathrm{RR}_{01}+\mathrm{RR}_{10}-2\right)$, in which $\mathrm{RR}_{11}=$ relative risk of the joint effect of two risk factors; $\mathrm{RR}_{01}$ and $\mathrm{RR}_{10}=$ relative risk of each risk factor in the absence of the other. Two hundred and forty-one subjects including $4 \mathrm{HCC}$ cases had no information on HBsAg or anti-HCV, and were excluded from the analysis.

There were $14 \mathrm{HBV} / \mathrm{HCV}$ coinfected study participants, of which 3 were $\mathrm{HCC}$ cases. Age- and sex-adjusted HRs of $\mathrm{HBV}$ monoinfection, $\mathrm{HCV}$ monoinfection and $\mathrm{HBV} / \mathrm{HCV}$ coinfection for $\mathrm{HCC}$ were 17.1 (95\% $\mathrm{CI}=8.4-34.8), 10.4$ (95\% CI=4.9-22.1) and 115.0 (95\% CI=32.5-407.3), respectively. The synergistic effect of $\mathrm{HBV} / \mathrm{HCV}$ coinfection was more than additive and was statistically significant ( $\mathrm{SI}=4.5$, 95\% CI=1.3-15.5) (Table 3).

Additional file 1: Table S1 shows the distribution of HCV genotypes among $142 \mathrm{HCV}$ RNA-positive subjects in the study population. As shown in Table 4, HCV genotype 1 (mostly 1b) significantly elevated HCC risk (adjusted $\mathrm{HR}=29.7,95 \% \mathrm{CI}=13.6-46.8$ ), whereas genotype 2 did not. HR of HCC in individuals multiply infected with $\mathrm{HCV}$ genotype 1 and 2 (adjusted $\mathrm{HR}=68.7$, 95\% $\mathrm{CI}=16.4-288.4$ ) was much higher than in monotypic infection with genotype 1 but the $95 \%$ CI was very wide and overlapped. The adjusted HR for past history of $\mathrm{HCV}$ infection (anti-HCV-positive but HCV RNA-negative) was 2.6 (95\% CI=0.6-11.5) (Table 4).

The population-attributable fraction of HCC due to HBV and HCV infection were 36.9\% (95\% CI=20.0-50.2\%) and $26.6 \%$ (95\% CI=11.3-39.2\%), respectively, in the study population (data not shown).

\section{Discussion}

The present study provides a comprehensive estimation of HCC risk according to HBV and HCV mono- and coinfection, using data from a community-based prospective cohort study in an area of Korea where $\mathrm{HCC}$ incidence is high. HBV is by far the most important risk factor for HCC in Korea. To our knowledge, this is the first study to explore the risk of $\mathrm{HCV}$ and discover the synergistic effect of HBV/HCV coinfection for HCC in a prospective cohort study in the general Korean population. Furthermore, in the current study it was evident that $\mathrm{HCV}$ genotype $1 \mathrm{~b}$ increased $\mathrm{HCC}$ risk significantly more than genotype 2 .

The role of chronic infection with HBV in the etiology of HCC is well established [1,2]. A community-based prospective cohort study titled the Risk Evaluation of Viral Load Elevation and Associated Liver Disease/ Cancer-Hepatitis B Virus (REVEAL-HBV) study in Taiwan has reported high serum HBV DNA level, HBV genotype C, precore G1896A mutant and basal core promoter A1762T/G1764A double mutant as predictors of HCC risk $[9,27]$. The adjusted HR (13.7) of HCC by HBsAg positivity in the present study was compatible with previous study results, including two recent meta-analyses: one that included 37 case-control and 10 cohort studies conducted worldwide [5], and another that used Korean data [15]. In addition, the risk of HCC by HBV infection was around two-fold higher than by HCV infection in present study.

One recent meta-analysis estimated the RR of HCC to be as much as 12-fold higher in people infected with $\mathrm{HCV}$ [5]. However, in Korea, there was no report of the RR of HCV, although some case-control studies reported

Table 4 Hazard ratios (HRs) and 95\% confidence intervals (Cls) of hepatocellular carcinoma (HCC) according to hepatitis $\mathrm{C}$ virus infection status and genotype

\begin{tabular}{|c|c|c|c|c|c|c|c|c|}
\hline Anti-HCV & $\begin{array}{l}\text { HCV } \\
\text { RNA }\end{array}$ & $\begin{array}{l}\text { HCV } \\
\text { genotype }\end{array}$ & $\begin{array}{l}\text { No. of } \\
\text { subjects }\end{array}$ & No. of HCC & Person-years & $\begin{array}{l}\text { Incidence } \\
(100,000 \text { person-year) }\end{array}$ & $\mathrm{HR}^{\mathrm{a}}(95 \% \mathrm{Cl})$ & $\mathrm{HR}^{\mathrm{b}}(95 \% \mathrm{CI})$ \\
\hline Negative & & & 6083 & 31 & $56,516.3$ & 54.9 & 1.0 (reference) & 1.0 (reference) \\
\hline \multirow[t]{4}{*}{ Positive } & Positive & 1 & 52 & 8 & 476.5 & $1,678.9$ & $28.3(13.0-61.5)$ & $29.7(13.6-46.8)$ \\
\hline & & 2 & 84 & 1 & 850.7 & 117.6 & $2.1(0.3-15.4)$ & $2.2(0.3-16.2)$ \\
\hline & & $1 \& 2$ & 6 & 2 & 51.1 & $3,913.9$ & $65.0(15.5-272.3)$ & $68.7(16.4-288.4)$ \\
\hline & Negative & & 109 & 2 & $1,045.2$ & 191.4 & $3.4(0.8-14.4)$ & $2.6(0.6-11.5)$ \\
\hline
\end{tabular}

${ }^{\mathrm{a}} \mathrm{HR}$ : age- and sex-adjusted. ${ }^{\mathrm{b}} \mathrm{HR}$ : age-, sex- and HBsAg positivity-adjusted. Two hundred and thirty-six subjects including 2 HCC cases had no information on anti-HCV, and were excluded from the analysis. 
odds ratios for HCV [28-30], and a meta-analysis reported a pooled odds ratio of $\mathrm{HCC}$ of 11.5 for anti-HCV-positive individuals [15]. In this respect, the present study contributes more evident data on the effect of $\mathrm{HCV}$ infection on HCC risk in Korea to the scientific literature by reporting RRs from a prospective cohort study, although the RR of $\mathrm{HCC}$ by anti-HCV positivity was lower than expected.

The synergistic effect of $\mathrm{HBV} / \mathrm{HCV}$ coinfection on HCC risk ( $\mathrm{SI}=4.5,95 \% \mathrm{CI}=1.3-15.5)$ identified in this study was another meaningful finding. Indeed, $\mathrm{HBV} / \mathrm{HCV}$ coinfection is not uncommon, particularly in countries with a high prevalence of $\mathrm{HBV}$ or $\mathrm{HCV}$, as the two viruses share with some modes of transmission [5].

It was not clear if there is a risk difference between HCV genotype 1 and 2 regarding the previous studies in Korean, even though HCV genotype $1 b$ and $2 a$ are dominant. The present study suggested that the HR of HCC was significantly higher in individuals infected with HCV genotype 1 (adjusted $\mathrm{HR}=29.7,95 \% \mathrm{CI}=13.6-46.8$ ) than genotype 2 (adjusted $\mathrm{HR}=2.2,95 \% \mathrm{CI}=0.3-16.2$ ). This strongly supports the results from a recent metaanalysis, which suggested that subjects infected with HCV genotype $1 b$ had almost double the HCC risk of those infected with other $\mathrm{HCV}$ genotypes [8]. Moreover, the present study showed multiplicative increase in HR of HCC in individuals who had mixed infection with $\mathrm{HCV}$ genotype 1 and 2 (adjusted $\mathrm{HR}=68.7,95 \% \mathrm{CI}=16.4$ 288.4), compared to HR of solitary genotype 1 or 2 infection. To the best of our knowledge, our study is the first to show this multiplicative relationship. HCV genotype is an important determinant of the virologic response to $\mathrm{HCV}$ treatment, whereas differences in disease pathogenesis among genotypes may also exist. Genotype 1 is associated with a more aggressive disease, worse response to therapy, and higher risk of cirrhosis and HCC development [8]. There are limited studies on HCV mixed genotype infection among high-risk individuals [31,32] but pathogenecity of mixed infection and its effect on disease progression and treatment have not yet been elucidated. On the other hand, HBV genotype was not evaluated in the present study as genotype $C$ was predominant (99\%) among the HBV genotypes in Koreans [16-18]. In the REVEAL study, HBV genotype $C$ showed higher risk of developing $\mathrm{HCC}(\mathrm{aRR}=1.76$; 95\% $\mathrm{CI}=1.19-2.61)$ and cirrhosis compare to HBV genotype B [33].

There is convincing evidence that alcohol drinking and tobacco smoking increase the risk of primary HCC [34-36] and synergistic effects between hepatitis infection and tobacco smoking or alcohol drinking in the development of HCC has been recently suggested [37-41]. Heavy alcohol drinking significantly elevated HCC risk after adjustment in this study. Tobacco smoking elevated HCC risk in the crude analysis, but was not significant after adjustment. Neither FBS level or obesity were related to
HCC risk in this study, although there is growing evidence suggesting that obesity and diabetes mellitus (DM) might be independent risk factors for HCC [20,39,42-45]. There was a substantial amount of missing information on FBS (27\% of the study population). However, the HCC risk was not statistically significant $(\mathrm{aHR}=1.7,95 \%$ $\mathrm{CI}=0.9-3.4)$ in the group of unknown FBS. In addition, the HCC risk was not elevated among subjects with DM history, as a proxy of FBS in the independent regression analysis (data not shown). Insignificant result of DM and obesity in risk of HCC development may be due to predominant role of HBV and HCV as a risk factor of HCC in this study population. Dietary ingestion of aflatoxins, one of the risk factor of HCC in developing countries, is very rare in Korea.

The present study offers comprehensive scientific evidence on the effect of HBV and HCV infection, as well as some other potential risk factors, on HCC development. Nevertheless, it has several limitations that should be considered when interpreting its data. Firstly, the size of the case population was not very large (50 HCC cases). In particular, a very small number of $\mathrm{HCC}$ cases were identified in each category of HCV genotype, including only $1 \mathrm{HCC}$ case in the group infected with HCV genotype 2. Coinfection with HCV genotype 1 and 2 showed higher HR than genotype 1 alone, but their 95\% CI were very wide and overlapping due to small number of $\mathrm{HCC}$ cases. However, considering the relatively lower prevalence of $\mathrm{HCV}$ infection in Korea, and the results of this community-based long-term prospective follow-up study are valid enough to support a causal relationship. Secondly, the risk factors were investigated at cohort enrollment, with no repeated measure. Thus there were no considerations of updated information for changes in infection status, interventions for liver diseases and/or health behaviors that took place after study recruitment. Thirdly, viral load of HBV and HCV infection was not evaluated in this study. Serum HBV DNA level is a major predictor of HCC development [9]. Patients with a high viral load of $\mathrm{HCV}$ respond poorly to interferon therapy [46] and had a significantly higher HCC risk (RR, 2.35; 95\% CI, 1.02-5.43) than did those with a low viral load after interferon treatment [47]. However the current study could not provide HCC risk by viral load of HBV and $\mathrm{HCV}$.

Compared to hospital-based case-control studies in Korea (HBsAg 65.4-72.3\%; anti-HCV 7.6-19.3\%) [28-30], the seroprevalence of HBsAg (39.1\%) and anti-HCV (32.6\%) among HCC cases in the present study was relatively low. Although the serological evidence of chronic infection with HBV and $\mathrm{HCV}$ remains relatively constant over time, there is a possibility that infection status can change between baseline and at diagnosis of HCC. Otherwise occult HBV or HCV infection may exist in 
HCC cases that are negative for markers of HBV and $\mathrm{HCV}$ infection. Recently there has been growing evidence of occult HBV and HCV infection. Occult HBV infection was found in $0.7 \%$ of HBsAg-negative individuals in the general adult population in Korea [48]. Although the mechanism and clinical implications have not yet been elucidated, occult HBV infection can also be transmitted and may contribute to the development of HBVassociated diseases such as HCC $[49,50]$.

Nevertheless, this study also has much strength. It is a prospective community-based cohort study that was able to link to a national cancer registry to evaluate the causal relationship of $\mathrm{HBV}, \mathrm{HCV}$ and other behavioral risk factors with HCC development, while all previous cohort studies reporting the RRs of HCC by viral hepatitis infection have used secondary data (i.e., medical insurance claims) and included no information about HCV infection and related behavioral risk factors (e.g., blood transfusion and acupuncture) [45,51,52]. In addition, the present study provides additional evidence on HCC in an HBV endemic area with comprehensive analyses of $\mathrm{HCV}$ infection, especially for different $\mathrm{HCV}$ genotypes and coinfection with HBV.

\section{Conclusions}

The present findings add to previous observations suggesting that $\mathrm{HBV}$ infection is by far the most important risk factors for HCC in HCC prevalent and HBV endemic areas. Furthermore, investigation of the distribution of different $\mathrm{HCV}$ genotypes, as well as the differences in HCC risk by HCV genotype and its coinfection with HBV, may significantly contribute to disease control, or progresses in prevention, such as the development of an effective vaccine, or implementation of an HCC screening program, to improve disease outcome.

\section{Additional file}

Additional file 1: Table S1. Distribution of hepatitis $\mathrm{C}$ virus (HCV) genotypes among 142 HCV RNA-positive subjects in the study population.

\section{Abbreviations}

anti-HBs: Antibodies against HBsAg; anti-HCV: Antibodies against HCV; ALT: Alanine aminotransferase; AST: Aspartate aminotransferase; BMI: Body mass index; Cl: Confidence interval; HBsAg: Hepatitis B surface antigen; HBV: Hepatitis B virus; HCV: Hepatitis C virus; HCC: Hepatocellular carcinoma; HR: Hazard ratio; RR: Relative risk; SI: Synergy index.

\section{Competing interests}

The authors declare that they have no competing interests.

\section{Authors' contributions}

JKO carried out the field survey, conducted the analysis of the data and drafted the manuscript. HRS designed and conducted the study, and drafted and revised the manuscript. MKL participated in conducting the field study and helped to revision the manuscript. HC performed the statistical analysis.
DIK carried out the serologic tests. YJ and HY carried out the genotyping. KYY conceived of the study, and participated in its design and coordination. All authors read and approved the final manuscript.

\section{Acknowledgements}

This study was financially supported by the National Cancer Center, Republic of Korea (grant no. NCC-1010230). The funder had no role in study design, data collection and analysis, decision to publish, or preparation of the manuscript. The authors would like to give special thanks to all collaborators of the Haman public health center for their supporting to implement field survey. We are also very grateful to Mi-Jin Bae (National Cancer Center, Republic of Korea) for her wonderful statistical assistance.

\section{Author details}

${ }^{1}$ National Cancer Control Institute, National Cancer Center, Goyang, Republic of Korea. ${ }^{2}$ Non Communicable Diseases and Health Promotion, World Health Organization Western Pacific Regional Office, 1000 UN Avenue, Manila, Philippines. ${ }^{3}$ Department of Occupational and Environmental Medicine, Samsung Medical Center, Sungkunkwan University School of Medicine, Suwon, Republic of Korea. ${ }^{4}$ Expanded Programme on Immunization, World Health Organization Western Pacific Regional Office, Manila, Philippines.

${ }^{5}$ Division of Enteric and Hepatitis Viruses, National Institute of Health, Korea Centers for Disease Control and Prevention, Osong, Republic of Korea.

${ }^{6}$ Department of Preventive Medicine, Seoul National University College of Medicine, Seoul, Republic of Korea.

Received: 26 April 2012 Accepted: 1 October 2012

Published: 5 October 2012

\section{References}

1. IARC: IARC monographs on the evaluation of carcinogenic risks to humans, Volume 59, Hepatitis viruses. Lyon: International Agency for Research on Cancer; 1994.

2. IARC: IARC monographs on the evaluation of carcinogenic risks to humans, Volume 100B, Biological agents. Lyon: International Agency for Research on Cancer; 2011.

3. Parkin DM: The global health burden of infection-associated cancers in the year 2002. Int J Cancer 2006, 118(12):3030-3044.

4. Bruno S, Crosignani A, Maisonneuve P, Rossi S, Silini E, Mondelli MU: Hepatitis $C$ virus genotype $1 \mathrm{~b}$ as a major risk factor associated with hepatocellular carcinoma in patients with cirrhosis: a seventeen-year prospective cohort study. Hepatology 2007, 46(5):1350-1356.

5. Cho LY, Yang JJ, Ko KP, Park B, Shin A, Lim MK, Oh JK, Park S, Kim YJ, Shin $H R$, et al: Coinfection of hepatitis $B$ and $C$ viruses and risk of hepatocellular carcinoma: systematic review and meta-analysis. Int J Cancer 2011, 128(1):176-184.

6. Donato F, Boffetta P, Puoti M: A meta-analysis of epidemiological studies on the combined effect of hepatitis $B$ and $C$ virus infections in causing hepatocellular carcinoma. Int J Cancer 1998, 75(3):347-354.

7. Lin CL, Kao JH: The clinical implications of hepatitis $B$ virus genotype: Recent advances. J Gastroenterol Hepatol 2011, 26(Suppl 1):123-130.

8. Raimondi S, Bruno S, Mondelli MU, Maisonneuve P: Hepatitis C virus genotype $1 \mathrm{~b}$ as a risk factor for hepatocellular carcinoma development: a meta-analysis. J Hepatol 2009, 50(6):1142-1154.

9. Iloeje $\mathrm{UH}$, Yang HI, Chen $\mathrm{CJ}$ : Natural history of chronic hepatitis B: what exactly has REVEAL Revealed? Liver Int 2012, 32(9):1333-1341.

10. Bahri O, Ezzikouri S, Alaya-Bouafif NB, Iguer F, Feydi AE, Mestiri H, Benazzouz $M$, Khalfallah T, Afifi R, Elkihal $L$, et al: First multicenter study for risk factors for hepatocellular carcinoma development in North Africa. World J Hepatol 2011, 3(1):24-30.

11. Wang CH, Mo LR, Chang KK, Lin RC, Kuo JJ: A cohort study to investigate hepatocellular carcinoma risk in hepatitis $C$ patients. HepatoGastroenterology 2011, 58(107-108):904-908.

12. Jung KW, Park S, Kong HJ, Won YJ, Lee JY, Park EC, Lee JS: Cancer statistics in Korea: incidence, mortality, survival, and prevalence in 2008. Cancer Res Treat 2011, 43(1):1-11.

13. Shin HR: Epidemiology of hepatitis C virus in Korea. Intervirology 2006, 49 $(1-2): 18-22$.

14. Korea Centers for Disease Control and Prevention: Korea Health Statistics 2009: Korea National Health and Nutrition Examination Survey (KNHANES IV-3). Seoul; 2010 
15. Shin A, Park S, Shin HR, Park EH, Park SK, Oh JK, Lim MK, Choi BY, Boniol M, Boffetta P: Population attributable fraction of infection-related cancers in Korea. Ann Oncol 2011, 22(6):1435-1442

16. Cho JH, Yoon KH, Lee KE, Park DS, Lee YJ, Moon HB, Lee KR, Choi CS, Cho EY, Kim HC: Distribution of hepatitis B virus genotypes in Korea. Korean J Hepatol 2009, 15(2):140-147.

17. Kim H, Jee YM, Song BC, Shin JW, Yang SH, Mun HS, Kim HJ, Oh EJ, Yoon $\mathrm{JH}, \mathrm{Kim} Y \mathrm{~J}$, et al: Molecular epidemiology of hepatitis B virus (HBV) genotypes and serotypes in patients with chronic HBV infection in Korea. Intervirology 2007, 50(1):52-57.

18. Song BC, Cui XJ, Kim H: Hepatitis B virus genotypes in Korea: an endemic area of hepatitis B virus infection. Intervirology 2005, 48(2-3):133-137.

19. Bouvard V, Baan R, Straif K, Grosse Y, Secretan B, El Ghissassi F, BenbrahimTallaa L, Guha N, Freeman C, Galichet L, et al: A review of human carcinogens-Part B: biological agents. Lancet Oncol 09, 10(4):321-322.

20. Gwack J, Hwang SS, Ko KP, Jun JK, Park SK, Chang SH, Shin HR, Yoo KY: Fasting serum glucose and subsequent liver cancer risk in a Korean prospective cohort. J Prev Med Public Health 2007, 40(1):23-28.

21. Yoo KY, Shin HR, Chang SH, Lee KS, Park SK, Kang D, Lee DH: Korean Multicenter Cancer Cohort Study including a Biological Materials Bank (KMCC-I). Asian Pac J Cancer Prev 2002, 3(1):85-92.

22. Alcohol and Public Health: Frequently Asked Questions.http://www.cdc.gov/ alcohol/fags.htm

23. WHO expert consultation: Appropriate body-mass index for Asian populations and its implications for policy and intervention strategies. Lancet 2004, 363(9403):157-163

24. Okamoto H, Tokita H, Sakamoto M, Horikita M, Kojima M, lizuka H, Mishiro S: Characterization of the genomic sequence of type $V$ (or 3a) hepatitis C virus isolates and PCR primers for specific detection. J Gen Virol 1993, 74:2385-2390

25. Andersson T, Alfredsson L, Kallberg H, Zdravkovic S, Ahlbom A: Calculating measures of biological interaction. Eur J Epidemiol 2005, 20(7):575-579.

26. Rothman KJ: The estimation of synergy or antagonism. Am J Epidemiol 1976, 103(5):506-511.

27. Chen CJ, Yang HI: Natural history of chronic hepatitis B REVEALed. $J$ Gastroenterol Hepatol 2011, 26(4):628-638.

28. Shin HR, Lee CU, Park HJ, Seol SY, Chung JM, Choi HC, Ahn YO, Shigemastu T: Hepatitis B and C virus, Clonorchis sinensis for the risk of liver cancer: a case-control study in Pusan, Korea. Int J Epidemiol 1996, 25(5):933-940.

29. Ahn HS, Kim MH, Kim YS, Kim JS: A Case-control Study on Association Between Hepatocellular Carcinoma and Infection of Hepatitis B and Hepatitis C Virus. Korean J Prev Med 1997, 30(1):1-16

30. Huh K, Lee JK, Choi SY, Hong SI, Lee DS: A Study on the Prevalence of $\mathrm{HBsAg}$ and Anti-HCV in Patients with Hepatocellular Carcinoma: Comparative Study with Healthy Blood Donors. Korean J Clin Pathol 1998 18(3):458-463

31. Pham ST, Bull RA, Bennett JM, Rawlinson WD, Dore GJ, Lloyd AR, White PA Frequent multiple hepatitis $C$ virus infections among injection drug users in a prison setting. Hepatology 2010, 52(5):1564-1572.

32. Qian KP, Natov SN, Pereira BJ, Lau JY: Hepatitis C virus mixed genotype infection in patients on haemodialysis. J Viral Hepat 2000, 7(2):153-160.

33. Yang HI, Yeh SH, Chen PJ, lloeje UH, Jen CL, Su J, Wang LY, Lu SN, You SL, Chen DS, et al: Associations between hepatitis B virus genotype and mutants and the risk of hepatocellular carcinoma. J Natl Cancer Inst 2008, 100(16):1134-1143.

34. Tanaka K, Tsuji I, Wakai K, Nagata C, Mizoue T, Inoue M, Tsugane S: Alcohol drinking and liver cancer risk: an evaluation based on a systematic review of epidemiologic evidence among the Japanese population. Jpn J Clin Oncol 2008, 38(12):816-838

35. IARC: IARC monographs on the evaluation of carcinogenic risks to humans, Volume 96, Alcohol Consumption and Ethyl Carbamate. Lyon: International Agency for Research on Cancer; 2010.

36. IARC: IARC monographs on the evaluation of carcinogenic risks to humans, Volume 83, Tobacco smoke and involuntary smoking. Lyon: International Agency for Research on Cancer; 2004.

37. Fujita $Y$, Shibata A, Ogimoto I, Kurozawa $Y$, Nose $T$, Yoshimura T, Suzuki H, Iwai N, Sakata R, Ichikawa S, et al: The effect of interaction between hepatitis $C$ virus and cigarette smoking on the risk of hepatocellular carcinoma. Br J Cancer 2006, 94(5):737-739.

38. Hassan MM, Spitz MR, Thomas MB, El-Deeb AS, Glover KY, Nguyen NT, Chan W, Kaseb A, Curley SA, Vauthey JN, et al: Effect of different types of smoking and synergism with hepatitis $C$ virus on risk of hepatocellular carcinoma in American men and women: case-control study. Int J Cancer 2008, 123(8):1883-1891.

39. Marrero JA, Fontana RJ, Fu S, Conjeevaram HS, Su GL, Lok AS: Alcohol tobacco and obesity are synergistic risk factors for hepatocellular carcinoma. J Hepatol 2005, 42(2):218-224.

40. Hassan MM, Hwang LY, Hatten CJ, Swaim M, Li D, Abbruzzese JL, Beasley P, Patt YZ: Risk factors for hepatocellular carcinoma: synergism of alcohol with viral hepatitis and diabetes mellitus. Hepatology 2002, 36(5):1206-1213.

41. Yuan JM, Govindarajan S, Arakawa K, Yu MC: Synergism of alcohol, diabetes, and viral hepatitis on the risk of hepatocellular carcinoma in blacks and whites in the U.S. Cancer 2004, 101(5):1009-1017.

42. Chen CL, Yang HI, Yang WS, Liu CJ, Chen PJ, You SL, Wang LY, Sun CA, Lu $\mathrm{SN}$, Chen DS, et al: Metabolic factors and risk of hepatocellular carcinoma by chronic hepatitis B/C infection: a follow-up study in Taiwan. Gastroenterology 2008, 135(1):111-121.

43. Ohki T, Tateishi $R$, Sato T, Masuzaki R, Imamura J, Goto T, Yamashiki N, Yoshida $\mathrm{H}$, Kanai $\mathrm{F}$, Kato $\mathrm{N}$, et al: Obesity is an independent risk factor for hepatocellular carcinoma development in chronic hepatitis $C$ patients. Clin Gastroenterol Hepatol 2008, 6(4):459-464.

44. Polesel J, Zucchetto A, Montella M, Dal Maso L, Crispo A, La Vecchia C, Serraino D, Franceschi S, Talamini R: The impact of obesity and diabetes mellitus on the risk of hepatocellular carcinoma. Ann Oncol 2009, 20(2):353-357.

45. Jee SH, Ohrr H, Sull JW, Samet JM: Cigarette smoking, alcohol drinking, hepatitis B, and risk for hepatocellular carcinoma in Korea. $J$ Natl Cancer Inst 2004, 96(24):1851-1856.

46. Kato N, Yokosuka O, Omata M, Hosoda K, Ohto M: Detection of hepatitis C virus ribonucleic acid in the serum by amplification with polymerase chain reaction. J Clin Invest 1990, 86(5):1764-1767.

47. Kasahara A, Hayashi N, Mochizuki K, Takayanagi M, Yoshioka K, Kakumu S, lijima A, Urushihara A, Kiyosawa K, Okuda M, et al: Risk factors for hepatocellular carcinoma and its incidence after interferon treatment in patients with chronic hepatitis C. Hepatology 1998, 27(5):1394-1402.

48. Song EY, Yun YM, Park MH, Seo DH: Prevalence of occult hepatitis B virus infection in a general adult population in Korea. Intervirology 2009, 52 (2):57-62.

49. Allain JP: Occult hepatitis B virus infection: implications in transfusion Vox Sang 2004, 86(2):83-91.

50. Torbenson M, Thomas DL: Occult hepatitis B. Lancet Infect Dis 2002, 2(8):479-486.

51. Lee MS, Kim DH, Kim H, Lee HS, Kim CY, Park TS, Yoo KY, Park BJ, Ahn YO: Hepatitis $B$ vaccination and reduced risk of primary liver cancer among male adults: a cohort study in Korea. Int J Epidemiol 1998, 27(2):316-319.

52. Yoo KY, Heon K, Lee MS, Park BJ, Ahn YO, Lee HS, Kim CY, Park TS: A reconstructed cohort study on the hepatitis $B$ virus infection as a risk factor of liver cancer in Korea. J Korean Med Sci 1991, 6(4):319-324.

\section{doi:10.1186/1471-2407-12-452}

Cite this article as: Oh et al:: Multiplicative synergistic risk of hepatocellular carcinoma development among hepatitis B and C co-infected subjects in HBV endemic area: a community-based cohort study. BMC Cancer 2012 12:452.

\section{Submit your next manuscript to BioMed Central and take full advantage of:}

- Convenient online submission

- Thorough peer review

- No space constraints or color figure charges

- Immediate publication on acceptance

- Inclusion in PubMed, CAS, Scopus and Google Scholar

- Research which is freely available for redistribution 